increased public interest in them and higher standards are now expected.

Although dealing chiefly with the national museums, the provincial institutions will welcome the recommendation of the Commission that the grant (now at $£ 25,000$ ) administered by the Victoria and Albert Museum for purchases should be increased in the next financial year.

With regard to buildings, there are at least thirteen projects which are to be regarded as of particular urgency. These include reconstruction of the wardamaged galleries at the British Museum, planning and construction of the final quarter of the Tate Gallery, erection of a new herbarium and library wing at Kew, construction of north-east and northwest wings of the Royal Scottish Museum, work on a west wing of the National Museum of Wales and extension of the Museum block of the Welsh Folk Museum.

The Commission urges museums to aim at a steady and rapid improvement in all their services and recommends that staff should be appointed to carry this out. It considers that these services should including cataloguing existing collections, the extension of late opening, provision of automatic guide lectures, and restaurants.
The Commission reiterates its recommendations in the previous report concerning estate duty, and income tax and surtax. It is pointed out that as it is not the policy of museums to finance themselves by entrance fees, apart from minor sources, only the taxpayer and private benefactors remain. It is thus felt that all bequests of money or money's worth should be exempted from aggregation and payment of estate duty, and that this should hold even if the donor dies within a year from the making of the gift. It is also considered that tax reliefs should be made in respect of gifts of objects or money, as the present British system of taxation offers no incentive to a benefactor to give to museums and art galleries during his life-time.

Those associated with provincial museums-and there are about 800 in the British Isles-will welcome the information that the Commission hopes to complete the survey and report, with recommendations, during the summer of 1962 , possibly issuing an interim factual report some time in 1961. This will be awaited with great interest.

The report also includes an impressive survey of the individual institutions comprising the national museums in London, Edinburgh and Cardiff.

F. S. WALLIS

\title{
POPULATION MOVEMENTS AND MALARIA ERADICATION
}

$\mathrm{I}^{\mathrm{N}}$ the early months of 1960 , a World Health Organization consultant, Mr. R. Mansell Prothero, visited the Sudan, Uganda, Kenya, Somaliland, Tanganyika, Zanzibar, Southern Rhodesia, Nigeria and Ghana to study the effect of population move. ments on malaria eradication programmes. In his report (W.H.O. Chron., 15, No. $5-6 ; 1961)$ he observes that, although no method of measuring the extent of population instability has yet been devised, there ean be no doubt of the high degree of such instability in Africa.

In all countries and territories visited by Prothero, there are considerable population movements from permanent villages to farms and back again. These usually involve the erection of temporary shelters for migrants on the farms. In the Sudan, for example, people move from one area to another during the cotton-picking season; in Nigeria, during the dry season, people go the valleys where there is still water to irrigate the land. Gambia receives many temporary immigrants from neighbouring countries for groundnut cultivation. Cultivation, planting and weeding coincide with the early months of the rainy season when malaria vectors are on the increase, and when temporary shelters provide suitable resting places for them.

Although the harvesting of such products as groundnuts, cocoa, and cotton attracts a considerable amount of labour, in many parts of Africa it occurs after the peak of malaria transmission. The same cannot be said of movements of labour to mining, industrial and commercial undertakings, since these occur all the year round.

Nomadic movements of pastoral tribes, which are on a larger scale than other types of population movement, occur only in certain parts of Africa, such as northern Sudan and Somalia. Fixed settlements are foreign to the way of life of these tribes; moreover, the environment in which they live com- pels many of them to wander with their flocks and herds. The only religious movement of any large size are those of the West African Mohammedans, north-east towards Mecca; these cause some convergance on the Sudan, but do not involve so many people as the internal migrations of the population of the country itself.

Apart from those connected with farming, most of these population movements occur without respect for international or political boundaries. Their effect on the stability of populations is considerable, and in fact, all malarial eradication pilot projects now in operation in Africa are hampered by them. It has so far proved impossible to start a malaria eradication programme for a whole country in Africa, because there is not one that contains population movements within its own boundaries. To keep migrants out of an area by using some kind of cordon sanitaire would not be practicable, because there are so many ways in which an African can get through natural or man-made boundaries if he wishes to do so. International co-operation in malaria eradication would only be a partial solution. These population movements are a fundamental part of the 'way of life' of the people. Some, such as pastoral nomadism, are traditional; others, such as migrant labour, are of more recent development. In either case, they cannot within a short time be stopped or easily controlled.

The situation must be accepted, and if it raises problems in malaria eradication, it will be necessary to find ways of adjusting to it. Malariologists in Africa must try to circumvent the problems that population movements raise for them in their work. But how, for example, is it possible to deal with the nomad pastoralist whose movements do not appear to follow any fixed plan, and whose huts, being mostly composed of grass and leaves, are not susceptible to effective insecticide treatment? It is clear that there 
is no generally applicable solution to problems of this kind, and each of them must be considered individually on the same level as the malariological and entomological investigations that are now regarded as an essential part of malaria eradication programmes. Population distribution, settlement patterns, types of housing, farming practices, communications, water supplies and other relevant factors vary so much from one area to another that generalization is impossible. Geographical reconnaissance, as it now exists in eradication programmes, does not cover every aspect of population movement. Where necessary, it will have to be expanded to collect much wider information on the factors described, in order to understand the whole complex of physical environment, malaria parasites, vectors and people. It may then be possible to evolve the correct technique applicable to each individual local situation. The inclusion of professional geographers in some malaria teams for full-time work at the outset of a programme would be valuable; when they had collected the required information, it would not be necessary to retain their services, since tho geographical data could afterwards be kept up-to-date by a specially trained sanitarian. There is also a need for detailed individual study of every migration problem arising in the course of malaria eradication in tropical Africa.

\section{POLLUTION FROM REFUSE TIPS}

T WO problems associated with modern living conditions are the disposal of house refuse and the reclamation of land from which chalk, gravel or other material has been removed. The possibility of solving these two problems at one blow by tipping the refuse into worked-out pits is attractive, provided that this can be done safely and without nuisance.

One of the dangers of this procedure, which is widely practised, is that water supplies may be contaminated by drainage from the refuse. To study this problem the Minister of Housing and Local Government, in 1953, appointed a technical committee to supervise experiments on the tipping of refuse, with special reference to the pollution of underground water. These experiments were carried out in the Laboratory of the Government Chemist, and the report on the results has recently been published, together with the conclusions and recommendations of the Committee*.

Two series of experiments were made : one on refuse tipped dry and the other on refuse tipped into water. The vo ume and composition of the liquid draining from the pits were determined, and the purification effected by passing this liquid through sand and gravel was studied.

The Committee points out that the matter is complex, and is careful to avoid over-simplified

* Ministry of Housing and Locas Government. Pollution of Water by Tipped Refuse. Report of the Technical Committee on the Experimental Disposal of House Refuse in Wet and Dry Pits. (H.M.S.O., London, 1961.) 78 . conclusions in its report. It appears, however, that the results of the experiments are reasonably encour. aging and that, provided certain precautions are taken, the practice of tipping refuse may safely be continued and even extended. Although \& highly polluting liquid is produced by percolation of rainwater through refuse, the amount of organic pollution falls off relatively rapidly with time. In addition, when refuse is tipped dry, a considerable amount of rain has to fall on it before any drainage water is produced. Thus if the amount of rainfall reaching the refuse can be reduced by covering the material with an impermeable layer as soon as possible after tipping, the total load of pollution discharged from the pit will be decreased. This is one of the reasons why the Committee considers that, under comparable conditions, dry tipping is less likely than wet tipping to affect water supplies adversely. It does not, however, rule out the use of wet sites, for the experiments showed that considerable purification of the liquid can be effected by percolation of the water from the pit through the surrounding ground. One suggestion of the Committee is that refuse might be tipped first into a dry pit, where initial decomposition would occur, and that after about two years it should be transferred to a wet tip, leaving the first site to be used again.

It is not claimed that the experiments described were exhaustive, and several lines of investigation remain to be followed.

NORA H. JOHNSON

\section{TOXICOLOGY OF PENICILLIUM ISLANDICUM}

$\mathrm{T}$ OXICOLOGICAL research into the methanol extract of the furgus $P$. islandicum has been carried out since the spring of 1954 , with collaboration in the fields of mycology, chomistry and medicine. In five biological testings, methanol extract prepared from the fungus mat of $U b, U c$ or $E a$ strains was administered in the form of oil solution or water suspension to 150 mice and $10 \mathrm{rats}$, orally or subcutaneously, to observe pathological changes; in chemical testings, chemical fractionations of the methanol extract were carried out.

Biological data obsorved a few days after a singlo or several doses of the methanol extract had been administered have been summarized by $\mathrm{K}$. Uraguchi,
T. Tatsuno, M. Tsukioka, Y. Sakai, F. Sakai, Y. Kobayahi, M. Saito, M. Enomoto and M. Miyake of the Departments of Pharmacology and Pathology, Faculty of Medicine, University of Tokyo, Bunkyoku, Tokyo, Japan (Jap. J. Exp. Med., 31, No. 1; 1961), as follows: Acute symptoms of poisoning are developed in mice and rats, but their life-time is prolonged with reduced doses. Poison damages show that abnormal function of the liver is detectable by the bromsulphthalein retention test, and autopsy shows, in most of the liver, centrolobular necrosis, fatty metamorphosis of liver cells and interconnexion between the necrotic areas with subsequent collapse; in part of the liver there is vacuolation of liver cells 